\title{
Antibacterial and cytotoxic cytochalasins from the endophytic fungus Phomopsis sp. harbored in Garcinia kola (Heckel) nut
}

\author{
Jean-Bosco Jouda' ${ }^{1}$, Jean-de-Dieu Tamokou ${ }^{2,3^{*}}$, Céline Djama Mbazoa ${ }^{{ }^{*}}$, Clovis Douala-Meli ${ }^{4}$, Prodipta Sarkar ${ }^{3}$,
} Prasanta Kumar $\mathrm{Bag}^{3}$ and Jean Wandji

\begin{abstract}
Background: The continuous emergence of multidrug-resistant (MDR) bacteria drastically reduced the efficacy of our antibiotic armory and consequently, increased the frequency of therapeutic failure. The search for bioactive constituents from endophytic fungi against MDR bacteria became a necessity for alternative and promising strategies, and for the development of novel therapeutic solutions. We report here the isolation and structure elucidation of antibacterial and cytotoxic compounds from Phomopsis sp., an endophytic fungus associated with Garcinia kola nuts.
\end{abstract}

Methods: The fungus Phomopsis sp. was isolated from the nut of Garcinia kola. The crude extract was prepared from mycelium of Phomopsis sp. by maceration in ethyl acetate and sequentially fractionated by column chromatography. The structures of isolated compounds were elucidated on the basis of spectral studies and comparison with published data. The isolated compounds were evaluated for their antibacterial and anticancer properties by broth microdilution and 3-(4,5-dimethylthiazol-2-yl)-2,5-diphenyltetrazolium bromide methods respectively. The samples were also tested spectrophotometrically for their hemolytic properties against human red blood cells.

Results: The fractionation of the crude extract afforded three known cytochalasins including 18-metoxycytochalasin J (1), cytochalasins H (2) and J (3) together with alternariol (4). The cytochalasin compounds showed different degrees of antibacterial activities against the tested bacterial pathogens. Shigella flexneri was the most sensitive microorganism while Vibrio cholerae SG24 and Vibrio cholerae PC2 were the most resistant. Ampicillin did not show any antibacterial activity against Vibrio cholerae NB2, Vibrio cholerae PC2 and Shigella flexneri at concentrations up to $512 \mu \mathrm{g} / \mathrm{mL}$, but interestingly, these multi-drug resistant bacterial strains were sensitive to the cytochalasin metabolites. These compounds also showed significant cytotoxic properties against human cancer cells $\left(\mathrm{LC}_{50}=3.66-35.69 \mu \mathrm{g} / \mathrm{mL}\right)$ with low toxicity to normal non-cancer cells.

Conclusion: The three cytochalasin compounds isolated from the Phomopsis sp. crude extract could be a clinically useful alternative for the treatment of cervical cancer and severe infections caused by MDR Shigella and Vibrio cholerae.

Keywords: Garcinia kola, Endophytic fungi, Phomopsis sp, Metabolites, Cytochalasins, Antibacterial, Cytotoxic

\footnotetext{
* Correspondence: jtamokou@yahoo.fr; djamaceline@yahoo.com

${ }^{2}$ Department of Biochemistry, Faculty of Science, Laboratory of Microbiology and Antimicrobial Substances, University of Dschang, P.O. Box 67, Dschang, Cameroon

${ }^{1}$ Department of Organic Chemistry, Faculty of Science, University of Yaoundé

1, P.O. Box 812, Yaoundé, Cameroon

Full list of author information is available at the end of the article
} 


\section{Background}

Endophytic fungi are organisms that live inside the plant tissues and behave as plant hosts [1]. They have proven to be a rich source of novel organic compounds with interesting biological activities and a high level of biodiversity $[2,3]$. Natural products from endophytic fungi have been observed to inhibit or kill a wide variety of harmful microorganisms including phytopathogens, as well as bacteria, fungi, viruses, and protozoans that affect humans and animals [4]. As one of the most frequently isolated secondary metabolites from endophytic fungi cultures, cytochalasins are produced by Phoma [5], Hormiscium [6], Helminthosporium [7], Phomopsis [8] and Curualuriu [9] genera. They have been identified as contaminants of potato [5], tomato [6], pecan [10], rice [11], millet [8] and litchi fruit [9]. The cytochalasins A, B, C, $\mathrm{D}$, and $\mathrm{E}$ are highly toxic to the chick, rat, mouse, and guinea pig [11-14] and are teratogenic to both chick and mouse [13, 15-17]. In recent years, most works on endophytic fungi have been centered on plants in the temperate and tropical regions of the world [18].

Plants of the genus Garcinia (family Clusiaceae), widely distributed in tropical Africa, Asia, New Caledonia and Polynesia, have yielded an abundance of biologically active and structurally intriguing natural products [19]. Garcinia species are known to contain a wide variety of oxygenated and prenylated xanthones, as well as polyisoprenylated benzophenones such as the guttiferones [20].

Garcinia kola (Clusiaceae) is a plant of West and Central African origin [21]. In Nigeria, the seed (Bitter kola) is chewed for the relief of cough, colds, colic, hoarseness of voice, and throat infections. The plant is also used for the treatment of liver disorders, jaundice, fever, and as a purgative and chewing sticks [21]. We focused on Garcinia kola nut because it is one of the most commercialized fruits in West and Central Africa, its highly valued perceived medicinal attributes, and the consumption of large quantities does not cause indigestion. However, several management strategies have been employed for their conservation, but the growth of the molds due to their moisture during that conservation remains a serious problem [22]. Moreover, further studies by Austin [23] attributed the loss of viability of kola nut seeds to reduction in moisture content.

During our investigation, the fungus Phomopsis sp. associated with that nut was found to be a producer of diverse secondary metabolites, including cytochalasins from its mycelium in potato dextrose agar (PDA) medium. Attracted by the potential production of this class of compounds, a so-called OSMAC (one strainmany compounds) [24] approach was carried out to find compounds. Following the application of the OSMAC principle, we found out that when the culture conditions were changed from PDA medium to solid state medium (rice), fermentation significantly changed and based on high-performance liquid chromatography (HPLC) monitoring, 18-metoxycytochalasin J (1), cytochalasins $\mathrm{H}$ (2) and J (3) and alternariol (4) were isolated. In this report, we evaluate the cytotoxic activities of cytochalasins against bacterial species and human cervical cancer cell lines, with emphasis on MDR Shigella flexneri and Vibrio cholerae.

\section{Methods}

\section{General experimental procedures}

High resolution mass spectra were obtained with an LTQ-Orbitrap Spectrometer (Thermo Fisher, USA) equipped with a HESI-II source. The spectrometer was operated in positive mode (1 spectrum/s; mass range: 100-1000) with nominal mass resolving power of 60000 at $\mathrm{m} / \mathrm{z} 400$ with a scan rate of $1 \mathrm{~Hz}$ ). It was equipped with automatic gain control to provide high-accuracy mass measurements within 2 ppm deviation using an internal standard; Bis (2-ethylhexyl) phthalate: $m / z=$ 391.28428. The spectrometer was attached with an Agilent (Santa Clara, USA) 1200 HPLC system consisting of LC-pump, PDA detector $(\lambda=260 \mathrm{~nm})$, auto sampler (injection volume $5 \mu \mathrm{L})$ and column oven $\left(30{ }^{\circ} \mathrm{C}\right)$. Following parameters were used for experiments: spray voltage $5 \mathrm{kV}$, capillary temperature $260{ }^{\circ} \mathrm{C}$, tube lens $70 \mathrm{~V}$. Nitrogen was used as a sheath gas (50 arbitrary units) and auxiliary gas (5 arbitrary units). Helium served as the collision gas. The separations were performed by using a Nucleodur C18 Gravity column $(50 \times 2 \mathrm{~mm}, 1.8 \mu \mathrm{m}$ particle size $)$ with a $\mathrm{H}_{2} \mathrm{O}(+0.1 \% \mathrm{HCOOH})(\mathrm{A}) /$ acetonitrile $(+0.1 \%$ $\mathrm{HCOOH}$ ) (B) gradient (flow rate $300 \mu \mathrm{L} / \mathrm{min}$ ). Samples were analyzed using a gradient program as follows: $80 \% \mathrm{~A}$ isocratic for $1 \mathrm{~min}$, linear gradient to $100 \%$ B over $18 \mathrm{~min}$, after $100 \%$ B isocratic for $5 \mathrm{~min}$, the system returned to its initial condition $(80 \% \mathrm{~A})$ within $0.5 \mathrm{~min}$, and was equilibrated for $4.5 \mathrm{~min}$. The separation was carried out by preparative HPLC run for 20 min on a Gilson apparatus with UV detection at $220 \mathrm{~nm}$ using a Nucleodur C18 Isis column (Macherey-Nagel, Düren, Germany), $5 \mu \mathrm{m}(250 \times$ $16 \mathrm{~mm}$ ) with a $\mathrm{H}_{2} \mathrm{O}(\mathrm{A}) / \mathrm{CH}_{3} \mathrm{OH}(\mathrm{B})$ gradient (flow rate $4 \mathrm{~mL} / \mathrm{min})$. Samples were separated by using a gradient program as follows: $60 \% \mathrm{~A}$ and $40 \% \mathrm{~B}$ isocratic for $2 \mathrm{~min}$, linear gradient to $100 \%$ B over $18 \mathrm{~min}$, after $100 \%$ B isocratic for $5 \mathrm{~min}$, the system returned to its initial condition $(60 \% \mathrm{~A})$ within $0.5 \mathrm{~min}$, and was equilibrated for $4.5 \mathrm{~min}$. The NMR spectra were recorded on a Bruker DRX-500 MHz spectrometer. Chemical shifts $(\delta)$ were quoted in parts per million (ppm) from internal standard tetramethylsilane and coupling constants (J) are in Hz. Silica gel [Merck, Kieselgel $60(0.063-0.200 \mathrm{~mm})$ ] was used for column chromatography. Melting points were determined on a BÜCHI melting point b-545 apparatus. UV spectra were measured with the earlier described spectrometer. 


\section{Isolation of endophytic fungus}

The fungus was isolated from the nut of Garcinia kola bought at Mokolo local market in Yaounde (Cameroon). The plant material was identified at the Cameroon National Herbarium, Yaoundé, where a voucher specimen $\left(\mathrm{N}^{\circ}\right.$ 27839/SRF-CAM) has been deposited. The seed was first cleaned by washing several times under running tap water and then cut into small slices, followed by successive surface sterilization in $70 \%$ ethanol and $\mathrm{NaOCl}(6-$ $14 \%$ active chlorine) for $2 \mathrm{~min}$ and finally with sterile distilled water for 2-3 times. The plant material was then dried in between the folds of sterile filter papers and deposited on a Petri dish containing potato dextrose agar medium (PDA) (200 g potato, $20 \mathrm{~g}$ dextrose, and $15 \mathrm{~g}$ agar in $1 \mathrm{~L}$ of $\mathrm{H}_{2} \mathrm{O}$, supplemented with $100 \mathrm{mg} / \mathrm{L}$ of chloramphenicol to suppress bacterial growth). All the plates were incubated at $28{ }^{\circ} \mathrm{C}$ to promote the growth of endophytes and were regularly monitored for any microbial growth. On observing the microbial growth, subculturing was done. Each endophytic culture was checked for purity and transferred to freshly prepared PDA plate

\section{Identification of the fungus CAM240}

Cultures were grown on PDA at $25^{\circ} \mathrm{C}$ under $12 \mathrm{~h} \mathrm{light} \mathrm{/}$ $12 \mathrm{~h}$ darkness cycles. The strain CAM240 formed abundant mycelium that filled out the Petri dishes $(9 \mathrm{~cm}$ diameter) in 8 days. The isolate was identified by $\mathrm{Dr}$ Clovis Douanla-Meli after macroscopic and microscopic examinations of its morphological features. Isolate was deposited as AGMy0319 in the Culture Collection of Federal Research Centre for Cultivated Plants (JKI), Braunschweig, Germany.

\section{Fungal culture and extraction}

Phomopsis sp. was cultured in 12 flat culture bottles containing $100 \mathrm{~g}$ rice and $100 \mathrm{~mL}$ water enriched with $0.3 \%$ peptone each, autoclaved at $121{ }^{\circ} \mathrm{C}$ for $45 \mathrm{~min}$. Each flask received about 5 small pieces of mycelium from PDA plate under sterile conditions. After 40 days of growth at $25{ }^{\circ} \mathrm{C}$, ethyl acetate $(12 \times 500 \mathrm{~mL})$ was added to each bottle, homogenized and filtered after $24 \mathrm{~h}$ and taken to dryness to afford $11.6 \mathrm{~g}$ of crude extract.

\section{Antibacterial assay \\ Microbial growth conditions}

A total of six bacterial strains were tested for their susceptibility to compounds and these strains were taken from our laboratory collection (kindly provided by Dr. T. Ramamurthy, NICED, Kolkata). Among the clinical strains of Vibrio cholerae used in this study, strains NB2 and SG24 and CO6 belonged to O1 and O139 serotypes, respectively. All these strains were able to produce cholera toxin and hemolysin and multi-drug-resistants (MDR). The other strains used in this study were $V$. cholerae non-O1, non-O139 (strain PC2); and Shigella flexneri SDINT. The MDR $V$. cholerae non-O1 and non-O139 strain PC2 isolated from aquatic environment was positive for hemolysin production but negative for cholera toxin production [25]. The American Type Culture Collection (ATCC) strain, Staphylococcus aureus ATCC 25923, was used for quality control. The bacterial strains were maintained on agar slant at $4{ }^{\circ} \mathrm{C}$ and subcultured on a fresh appropriate agar plates $24 \mathrm{~h}$ prior to any antibacterial test. The Mueller Hinton Agar (MHA) was used for the activation of bacteria. The Mueller Hinton Broth (MHB) and nutrient agar (HiMedia) were used for the MIC and MBC determinations respectively.

\section{Inocula preparation}

Suspensions of bacteria were prepared in MHB from cells arrested during their logarithmic phase growth $(4 \mathrm{~h})$ on $\mathrm{MHB}$ at $37^{\circ} \mathrm{C}$. The turbidity of the microbial suspension was read spectrophotometrically at $600 \mathrm{~nm}$ and adjusted to an OD of 0.1 with $\mathrm{MHB}$, which is equivalent to $1 \times 10^{8} \mathrm{CFU} / \mathrm{mL}$. From this prepared solution, other dilutions were made with $\mathrm{MHB}$ to yield $1 \times 10^{6} \mathrm{CFU} / \mathrm{mL}$.

\section{Determination of minimum inhibitory concentration (MIC)} and minimum bactericidal concentration $(\mathrm{MBC})$

MIC and MBC of compounds 1-3 were assessed using the broth microdilution method recommended by the National Committee for Clinical Laboratory Standards $[26,27]$ with slight modifications. Each test sample was dissolved in dimethylsulfoxide (DMSO) to give a stock solution. The 96-well round bottom sterile plates were prepared by dispensing $180 \mu \mathrm{L}$ of the inoculated broth $\left(1 \times 10^{6} \mathrm{CFU} / \mathrm{mL}\right)$ into each well. A $20 \mu \mathrm{L}$ aliquot of the stock solution of compound was added. The concentrations of sample tested were $0.125,0.25,0.50,1,2,4,8$, $16,32,64,128,256$ and $512 \mu \mathrm{g} / \mathrm{mL}$. The final concentration of DMSO in each well was $<1 \%$ [preliminary analyses with $1 \%(\mathrm{v} / \mathrm{v})$ DMSO did not inhibit the growth of the test organisms]. Dilutions of tetracycline and ampicillin served as positive controls, while broth with $20 \mu \mathrm{L}$ of DMSO was used as negative control. The ATCC strain Staphylococcus aureus ATCC 25923 was included for quality assurance purposes. Plates were covered and incubated for $24 \mathrm{~h}$ at $37^{\circ} \mathrm{C}$. After incubation, minimum inhibitory concentrations (MIC) were read visually; all wells were plated to nutrient agar (Hi-Media) and incubated. The minimal bactericidal concentration (MBC) was defined as a $99.9 \%$ reduction in CFU from the starting inoculums after $24 \mathrm{~h}$ incubation interval. 


\section{Cytotoxicity assay}

HeLa (Human cervical cancer cell line, ATCC No. CCL-2) and Vero cells (African green monkey kidney cells, normal non-cancer cells, ATCC No. CCL-81), obtained from the American Type Culture Collection (ATCC) were used in this study. Cytotoxic activity was determined using the 3(4,5-dimethylthiazol-2-yl)-2,5-diphenyltetrazolium bromide (MTT, Sigma, USA) assay reported by Mosmann [28] for the HeLa and Vero cells. This cell viability assay is based on living cell's property to transform the MTT dye tetrazolium ring into a purple-colored formazan structure due to the action of mitochondrial and other dehydrogenases inside the cell. The color intensity yielded by the cell population is directly proportional to the number of viable cells, and one can quantify the absorbance measurements using mathematical parameters. Each test sample was dissolved in dimethylsulfoxide (DMSO) to give a stock solution. Compounds 1-3 were prepared from the stock solutions by serial dilution in RPMI 1640 to give a volume of $100 \mu \mathrm{L}$ in each well of a microtiter plate (96-well). Each well was filled with $100 \mu \mathrm{L}$ of cells at $2 \times 10^{5}$ cells $/ \mathrm{mL}$. The assay for each concentration of compound was performed in triplicates and the culture plates were kept at $37{ }^{\circ} \mathrm{C}$ with $5 \%(\mathrm{v} / \mathrm{v}) \mathrm{CO}_{2}$ for $24 \mathrm{~h}$. After removing the supernatant of each well and washing twice by PBS, $20 \mu \mathrm{L}$ of MTT solution ( $5 \mathrm{mg} / \mathrm{mL}$ in PBS) and $100 \mu \mathrm{L}$ of medium were then introduced. After $4 \mathrm{~h}$ of incubation, $100 \mu \mathrm{L}$ of DMSO were added to each well to dissolve the formazan crystals and the absorbance values at $490 \mathrm{~nm}$ were measured with a microplate reader (Bio-RAD 680 , USA). The relative cell viability (\%) was expressed as a relative percentage of treated cells to the untreated control cells $(\mathrm{TC} / \mathrm{UC} \times 100)$. The rate of cell inhibition was calculated using the following formula: inhibition rate $=\left[1-\left(\mathrm{OD}_{\text {test }} / \mathrm{OD}_{\text {negative control }}\right)\right] \times$ $100 \%$. The $\mathrm{LC}_{50}$ values were calculated as the concentration of test sample resulting in a 50\% reduction of absorbance compared to untreated cells. Cells treated with 5-fluorouridine + RPMI 1640 served as positive control while cells left untreated + 1\% (v/v) DMSO + RPMI 1640 were used as negative control.

\section{Hemolytic assay}

Whole blood $(10 \mathrm{~mL})$ from a healthy man was collected into a conical tube containing heparin as an anticoagulant. Erythrocytes were harvested by centrifugation at room temperature for $10 \mathrm{~min}$ at $1,000 \times g$ and were washed three times in PBS solution. The top layer (plasma) and the next, milky layer (buffy coat with a layer of platelets on top of it) were then carefully aspirated and discarded. The cell pellet was resuspended in $10 \mathrm{~mL}$ of PBS solution and mixed by gentle aspiration with a Pasteur pipette. This cell suspension was used immediately.
For the normal human red blood cells, which were in suspension, the cytotoxicity was evaluated as previously described [29]. Compounds 1-3, at concentrations ranging from 32 to $512 \mu \mathrm{g} / \mathrm{mL}$, were incubated with an equal volume of $1 \%$ human red blood cells in phosphate buffered saline (10 mM PBS, pH 7.4) at $37{ }^{\circ} \mathrm{C}$ for $1 \mathrm{~h}$. Tetracycline was tested simultaneously. Non-hemolytic and $100 \%$ hemolytic controls were the buffer alone and the buffer containing $1 \%$ Triton X-100, respectively. Cell lysis was monitored by measuring the release of hemoglobin at $595 \mathrm{~nm}$ with a spectrophotometer (Thermo Scientific, USA). Percent hemolysis was calculated as follows: [ $(A 595$ of sample treated with compound - A595 of sample treated with buffer)/(A595 of sample treated with Triton X-100 - A595 of sample treated with buffer)] x 100 .

\section{Statistical analysis}

Statistical analysis was carried out using Statistical Package for Social Science (SPSS, version 12.0). The experimental results were expressed as the mean \pm Standard Deviation (SD). Group comparisons were performed using One Way ANOVA followed by Waller-Duncan Post Hoc test. A p value of 0.05 was considered statistically significant.

\section{Results and discussion Identification of the fungus}

Macroscopic examination of the isolate revealed that colonies were cottony, developing compact aerial mycelium, at first uniformly white (Fig. 1a) then becoming whitish with pale brown patches. The reverse side of cultures was whitish, then turned light brown with scattered darker spots which later appeared regularly concentrical. Conidiation began in 12-day old colonies with the formation of spherical, subglobose to ampuliform black stromata, measuring 210-250 × 220-380 $\mu \mathrm{m}$ and arranged in a circle in the Petri disch (Fig. 1a) and containing pycnidia. Watery exudate drops from pycnidia contained only beta conidia. These were 17-28.5 $\times$ 0.9-1.9 $\mu \mathrm{m}$, unicellular, hyaline, filiform and mostly slightly curved at one end (Fig. 1b).

Cultural and morphological features of the strain CAM240 enabled its reliable placement in the genus Phomopsis. There was noticeable morphological similarity with Phomopsis longicolla [30], a species generally known as a Soybean pathogen, but that can be isolated as endophyte from other different host plants. With reference to recent revision of species concept in Phomopsis, specific determination requires a muli-locus analysis of ITS, tef and ß-tubulin loci [31]. Therefore, taxonomy of strain CAM240 as based only on the morphology in this study was restricted to generic level. 


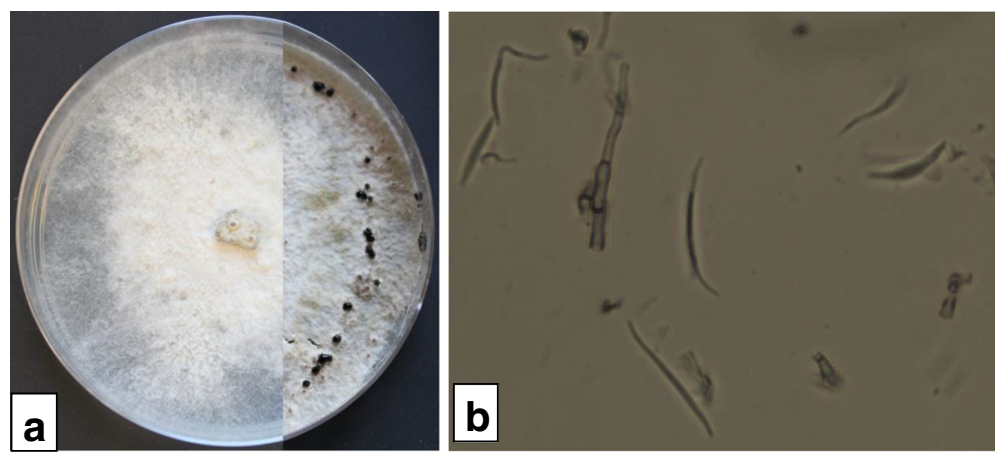

Fig. 1 Macroscopic (a) and microscopic (b) aspects of Phomopsis sp

\section{Chemical analysis}

The mycelium from Petri dish after ten days fermentation was extracted with $10 \mathrm{~mL}$ ethyl acetate. The obtained extract was submitted to HR-LC-MS and the major compounds were directly identified (Fig. 2). The crude extract $(11.60 \mathrm{~g})$ from the large scale fermentation was firstly submitted to HR-LC-MS and then chromatographed on a silica gel column $(0.04-0.063 \mathrm{~mm}, 6 \mathrm{~cm}$ x $60 \mathrm{~cm}, 100 \mathrm{~g})$ eluting with cyclohexane, mixture cyclohexane/ethyl acetate by increasing the polarity and finally with methanol. 56 fractions of $200 \mathrm{~mL}$ each were collected and combined according to TLC profile into 17 fractions. Each fraction was monitored by LC-MS and fractions 7, 10 and 16 were further purified by means of high performance reverse phase liquid chromatography to yield 3 cytochalasins: 18metoxycytochalasin $\mathrm{J}(1)\left(4.1 \mathrm{mg}, \mathrm{t}_{\mathrm{R}}=9.48 \mathrm{~min}\right)$ isolated as brown amorphous powder, its molecular formula was determined to be $\mathrm{C}_{29} \mathrm{H}_{39} \mathrm{O}_{4} \mathrm{~N}$ by its HRESIMS $\mathrm{m} / \mathrm{z}$ 466.29587 $[\mathrm{M}+\mathrm{H}]^{+}$(calculated 466.29573 for $[\mathrm{M}+\mathrm{H}]^{+}$) [32]; cytochalasin $\mathrm{H}(2)\left(136.2 \mathrm{mg}, \mathrm{t}_{\mathrm{R}}=8.94 \mathrm{~min}\right)$, isolated as white powder, HRESIMS $m / z$ 494.28949 $[\mathrm{M}+\mathrm{H}]^{+}$(calculated for $\mathrm{C}_{30} \mathrm{H}_{40} \mathrm{O}_{5} \mathrm{~N}$, 494.29065) [33]; cytochalasin J (3) (16.7 $\mathrm{mg}, \mathrm{t}_{\mathrm{R}}=7.41 \mathrm{~min}$ ) was obtained as white crystals, HRESIMS $m / z \quad 452.28052 \quad[\mathrm{M}+\mathrm{H}]^{+}$(calculated for

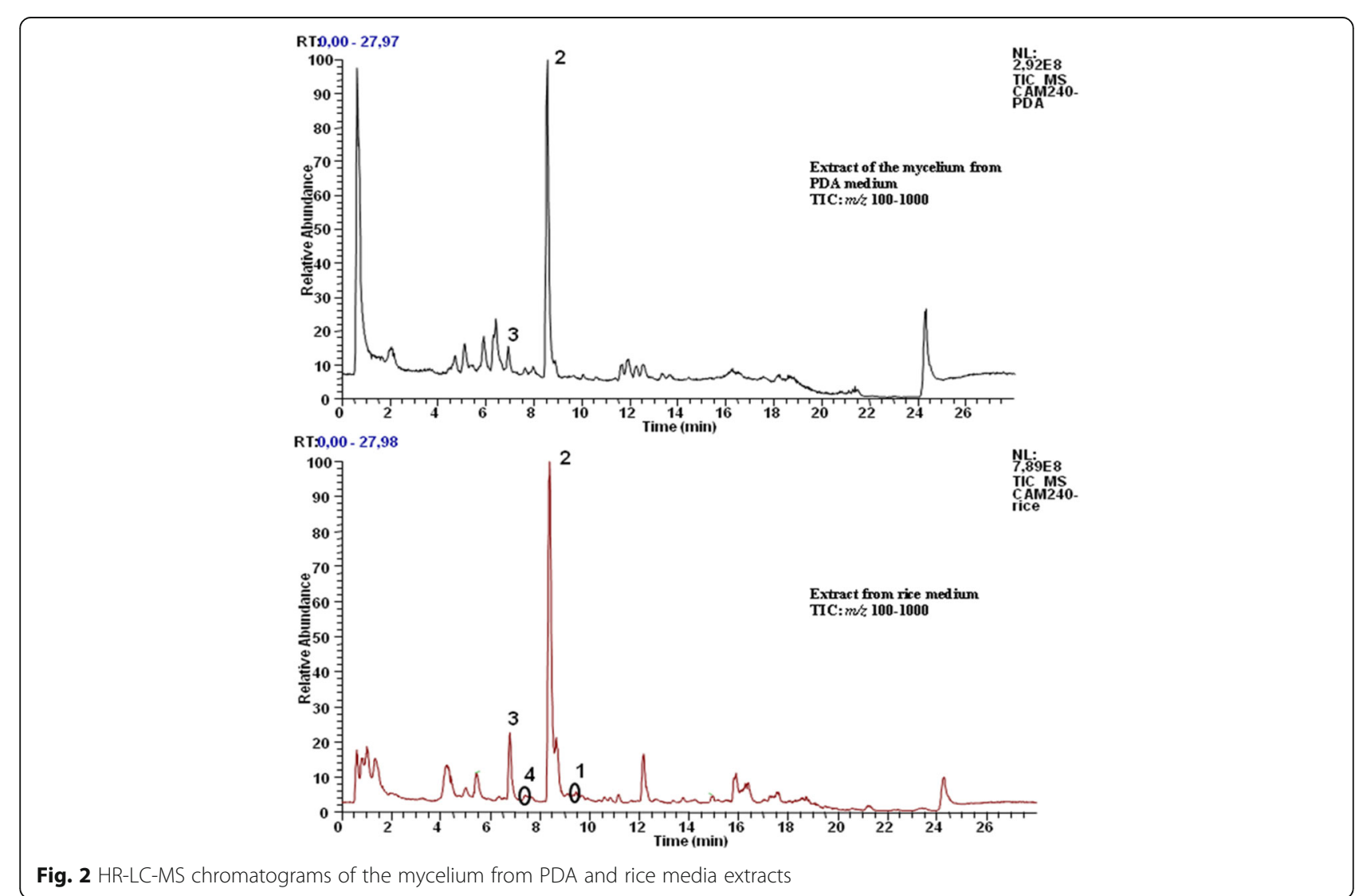


$\mathrm{C}_{28} \mathrm{H}_{38} \mathrm{O}_{4} \mathrm{~N}$, 452.28008) [34], was the major metabolite and alternariol (4) (5.3 $\mathrm{mg}, \mathrm{t}_{\mathrm{R}}=7.55 \mathrm{~min}$ ) as a white powder, HRESIMS $m / z 259.06009[\mathrm{M}+\mathrm{H}]^{+}$(calculated for $\left.\mathrm{C}_{14} \mathrm{H}_{11} \mathrm{O}_{5}, 259.06065\right)$ [35]. The chemical structures of the isolated compounds are shown in Fig. 3.

The chemical investigation of the crude extract from the rice medium of Phomopsis sp. harboring nut of Garcinia kola, by means of different chromatography techniques yielded four main compounds. Cytochalasins were the major secondary metabolites as detected and shown in Fig. 2, and this class of compounds is commonly found in Phomopsis genus.

\section{Antibacterial activity}

The cytochalasins showed different degrees of antibacterial activities against the tested bacterial pathogens (Table 1). Shigella flexneri SDINT was the most sensitive microorganism while Vibrio cholerae SG24 and V. cholerae PC2 were the most resistant. Ampicillin did not show any antibacterial activity against $V$. cholerae NB2, $V$. cholerae $\mathrm{PC} 2$, and Shigella flexneri SDINT at concentrations up to $512 \mu \mathrm{g} / \mathrm{mL}$ while these multi-drug resistant bacterial strains were found sensitive to the cytochalasin metabolites. This finding suggests the antibacterial potencies of these compounds in particular for the treatment of multi-drug-resistant (MDR) bacterial strains. Compounds 1, 2 and 3 showed selective activities; their inhibitory effects being noted respectively on $4 / 6(66.66 \%), 5 / 6(83.33 \%)$ and $4 / 6(66.66 \%)$ of the studied microorganisms. A keen look at the $\mathrm{MBC}$ values indicates that most of them are equal to their corresponding MICs. This proves that the killing effects of many tested samples could be expected on the sensitive strains [36].

The present study showed significant antibacterial activity of cytochalasin compounds against MDR entero-pathogenic bacteria including the clinical isolates of toxigenic Vibrio cholerae, the causative agents of dreadful disease cholera and Shigella sp., the causative agent of shigellosis. These compounds were having significant antibacterial activities against Gram-positive bacterium, Staphylococcus aureus. Although cytochalasin compounds have been reported to possess interesting activity against a wide range of microorganisms [37], no study has been reported on the activity of the metoxycytochalasin J (1), cytochalasins H (2) and J (3) against these types of pathogenic strains.

\section{Cytotoxicity activity}

Compounds 1-3 were evaluated for their anticancer against human cervical cancer cells (HeLa cells) (Table 2).

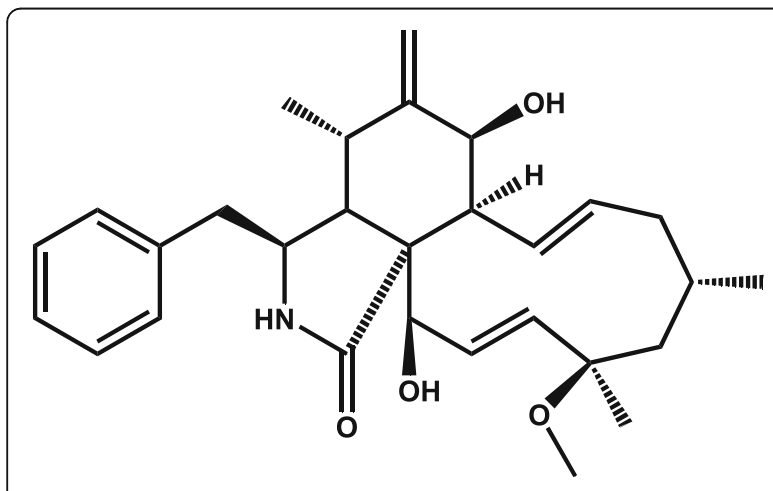

1

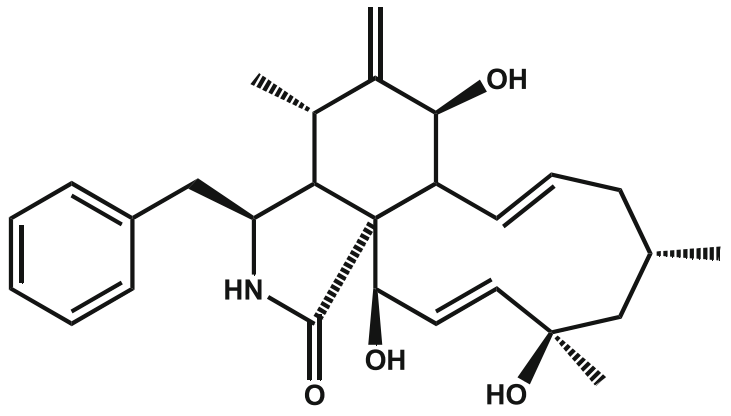

3

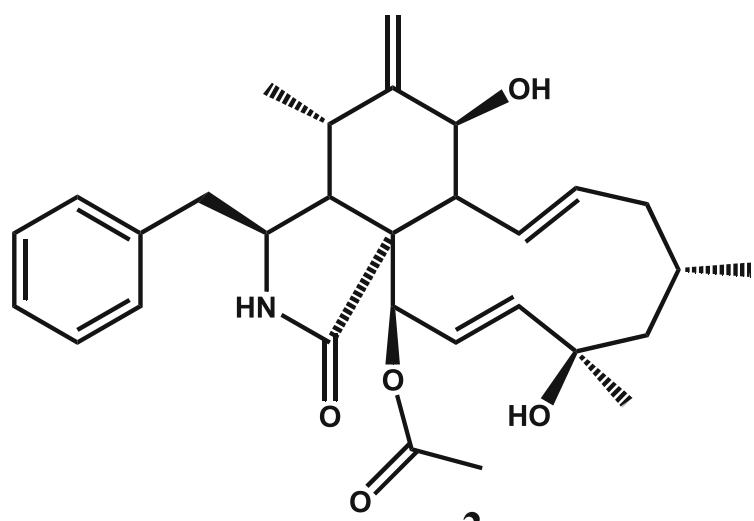

2

Fig. 3 Chemical structures of compounds 1-4 from Phomopsis sp. 1: 18-metoxycytochalasin J; 2: cytochalasin H; 3: cytochalasin J and 4: alternariol 
Table 1 Inhibition parameters (MIC, MBC) of compounds 1-3 and reference antibacterial drugs

\begin{tabular}{|c|c|c|c|c|c|c|c|}
\hline \multicolumn{8}{|c|}{ Antibacterial activity (MIC and $\mathrm{MBC}$ in $\mu \mathrm{g} / \mathrm{mL}$ ) } \\
\hline Compounds & Inhibition parameters & V. cholerae SG24 & V. cholerae CO6 & V. cholerae NB2 & V. cholerae PC2 & S. flexneri SDINT & S. aureus ATCC 25923 \\
\hline \multirow[t]{3}{*}{1} & MIC & $>512$ & 512 & 512 & $>512$ & 128 & 128 \\
\hline & MBC & $>512$ & 512 & 512 & $>512$ & 128 & 128 \\
\hline & $\mathrm{MBC} / \mathrm{MIC}$ & / & 1 & 1 & / & 1 & 1 \\
\hline \multirow[t]{3}{*}{2} & MIC & $>512$ & 512 & 512 & 256 & 128 & 256 \\
\hline & MBC & $>512$ & 512 & 512 & 256 & 128 & 256 \\
\hline & $\mathrm{MBC} / \mathrm{MIC}$ & / & 1 & 1 & 1 & 1 & 1 \\
\hline \multirow[t]{3}{*}{3} & MIC & $>512$ & 512 & 512 & $>512$ & 128 & 512 \\
\hline & MBC & $>512$ & 512 & 512 & $>512$ & 128 & 512 \\
\hline & MBC/MIC & / & 1 & 1 & / & 1 & 1 \\
\hline \multirow[t]{3}{*}{ Tetracycline } & $\mathrm{MIC}$ & 0.50 & 2 & 0.50 & 0.50 & 16 & 16 \\
\hline & MBC & 1 & 8 & 2 & 1 & 32 & 32 \\
\hline & MBC/MIC & 2 & 4 & 4 & 2 & 2 & 2 \\
\hline \multirow[t]{3}{*}{ Ampicillin } & MIC & 16 & 16 & $>512$ & $>512$ & $>512$ & 16 \\
\hline & $\mathrm{MBC}$ & 16 & 16 & $>512$ & $>512$ & $>512$ & 16 \\
\hline & $\mathrm{MBC} / \mathrm{MIC}$ & 1 & 1 & / & / & / & 1 \\
\hline
\end{tabular}

/ not determined; MIC Minimum Inhibitory Concentration; MBC Minimum Bactericidal Concentration

The lowest $\mathrm{LC}_{50}$ value (corresponding to the most cytotoxic compound) was found with compound $3\left(\mathrm{LC}_{50}=\right.$ $3.66 \mu \mathrm{g} / \mathrm{mL}$ ) followed in decreasing order by compound $1 \quad\left(\mathrm{LC}_{50}=8.18 \mu \mathrm{g} / \mathrm{mL}\right)$ and compound $2 \quad\left(\mathrm{LC}_{50}=\right.$ $35.69 \mu \mathrm{g} / \mathrm{mL}$ ) (Table 2). Interestingly, the cytotoxicity of compound 3 can be considered more important when taking into consideration the criterion of the American National Cancer Institute (NCI) regarding the cytotoxicity of pure compounds $\left(\mathrm{LC}_{50}<4 \mu \mathrm{g} / \mathrm{mL}\right)$ [38]. The data also showed that the tested compounds were most cytotoxic to HeLa cells $\left(\mathrm{LC}_{50}=3.66-\right.$ $35.69 \mu \mathrm{g} / \mathrm{mL})$ when compared with Vero cells $\left(\mathrm{LC}_{50}=\right.$ $73.88-129.10 \mu \mathrm{g} / \mathrm{mL}$ ) indicating that they are less toxic to normal cells. Our results are in agreement with those of Xu et al. [39] who showed the cytotoxicity activity of some cytochalasin compounds isolated from the solid substrate culture of Endothia gyrosa IFB-E023 against the human leukaemia $\mathrm{K} 562$ cell line with the $\mathrm{IC}_{50}$ values varying between 1.5 to $28.3 \mu \mathrm{M}$.
In the present study, Selectivity Index (SI) of active compounds was determined in order to investigate whether the cytotoxic activity was specific to cancer cells/bacterial strains. The SI of the samples are defined as the ratio of cytotoxicity ( $\mathrm{LC}_{50}$ values) on normal noncancer cells (Vero cells) to cancer cells (HeLa cells) or bacterial cells: $\mathrm{SI}=\mathrm{LC}_{50}$ on Vero cells $/ \mathrm{LC}_{50}$ on HeLa cells or MIC. Test agents with SI equal or higher than ten were considered to have high selectivity towards cancer cells [40]. Apart from compounds 1 and 3 on HeLa cells, the SI values of the tested samples against the HeLa cells and bacterial strains ranged from 0.14 to 3.61 and could be considered as poor.

\section{Hemolytic activity}

Human red blood cells provide a handy tool for toxicity studies of compounds, because they are readily available, their membrane properties are well known, and their lysis is easy to monitor by measuring the release of

Table 2 Cytotoxicity $\left(\mathrm{LC}_{50}\right.$ in $\mu \mathrm{g} / \mathrm{mL}$ ) of compounds $1-3$ and their selectivity index (SI)

\begin{tabular}{|c|c|c|c|c|c|c|c|c|c|}
\hline \multirow[t]{2}{*}{ Compounds } & \multicolumn{2}{|c|}{ Cytotoxicty $\left(\mathrm{LC}_{50}\right)$} & \multicolumn{7}{|c|}{ Selectivity Index* } \\
\hline & HeLa cells & Vero cells & HeLa cells & $\begin{array}{l}\text { V. cholerae } \\
\text { SG24 }\end{array}$ & V. cholerae CO6 & V. cholerae NB2 & V. cholerae PC2 & $\begin{array}{l}\text { S. flexneri } \\
\text { SDINT }\end{array}$ & $\begin{array}{l}\text { S. aureus ATCC } \\
25923\end{array}$ \\
\hline 1 & $8.18 \pm 0.92^{a}$ & $93.02 \pm 2.54^{\mathrm{a}}$ & 11.37 & / & 0.18 & 0.18 & / & 0.72 & 0.72 \\
\hline 2 & $35.69 \pm 1.31^{b}$ & $129.10 \pm 1.20^{b}$ & 3.61 & / & 0.25 & 0.25 & 0.50 & 1.00 & 0.50 \\
\hline 3 & $3.66 \pm 0.33^{c}$ & $73.88 \pm 0.92^{c}$ & 20.18 & / & 0.14 & 0.14 & / & 0.57 & 0.14 \\
\hline 5-FU & $0.25 \pm 0.05^{d}$ & $4.63 \pm 0.17^{d}$ & 18.52 & / & / & / & / & / & / \\
\hline
\end{tabular}

I: not determined; 5-FU 5-Fluorouridine; SI LC 50 on Vero cells /MIC or LC ${ }_{50}$ on HeLa cells; ${ }^{*}$ : SI obtained from average MIC. In the same column, $\mathrm{LC}_{50}$ value marked with different superscript letters $(a, b, c, d)$ are significantly different $(p<0.05)$ 


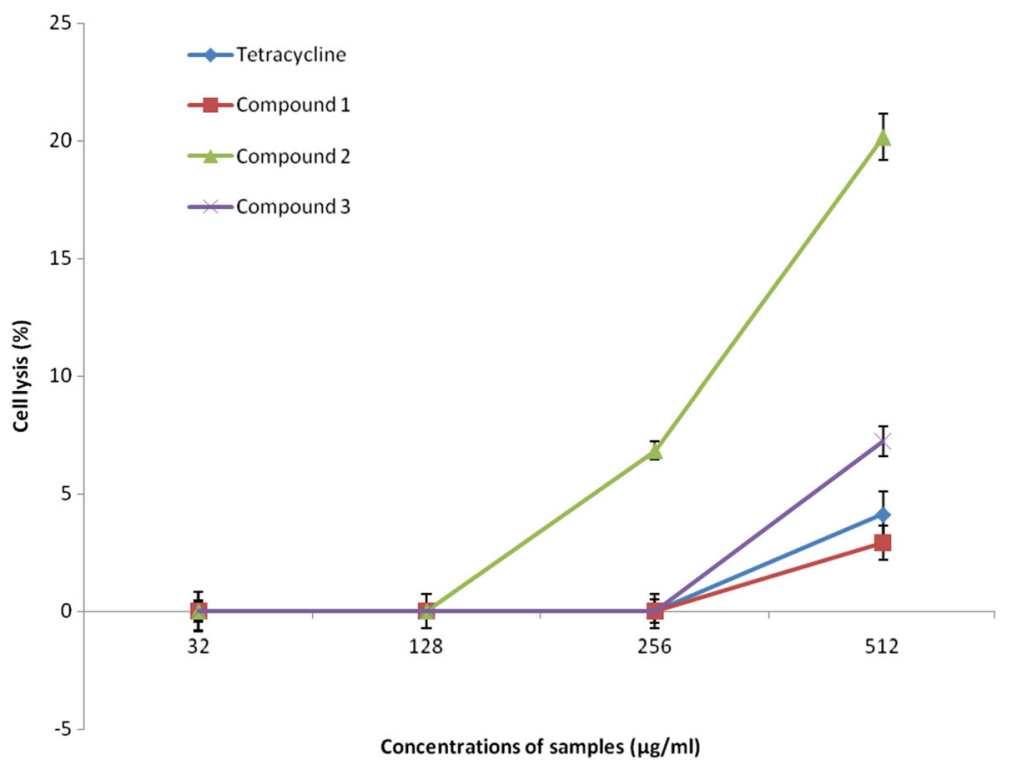

Fig. 4 Cytotoxicity of compounds 1-3 against red blood cells. The data are means of triplicate experiments

hemoglobin [29]. The hemolytic activities of compounds $1-3$, and tetracycline on human red blood cells (as a function of sample concentration) are shown in Fig. 4. At the highest concentration tested in this study $(512 \mu \mathrm{g} / \mathrm{mL})$, compounds 1,3 and tetracycline caused less than $10 \%$ hemolysis, while compound 2 caused $20.14 \%$ hemolysis.

\section{Conclusions}

The chemical study of the ethyl acetate extract of Phomopsis sp. mycelium afforded three known cytochalasins including 18-metoxycytochalasin $\mathrm{J}$ (1), cytochalasins $\mathrm{H}$ (2) and J (3) together with alternariol (4). Compounds 1, 2 and 3 showed different degrees of antibacterial activities against MDR clinical strains of enteropathogenic bacteria with low toxicity to human red blood cells and normal Vero cells. These compounds also showed significant cytotoxic properties against human cervical cancer cells. The overall results of this study indicate that cytochalasin compounds 1-3 isolated from the Phomopsis sp. mycelium could be a clinically useful alternative for the treatment of cervical cancer and severe infections in particular those caused by Shigella flexneri and Vibrio cholerae strains resistant to ampicillin.

\footnotetext{
Abbreviations

5-FU: 5-Fluorouridine; ATCC: American Type Culture Collection; DMSO: Dimethylsulfoxide; HMBC: Heteronuclear Multiple Bond

Connectivities; HPLC: High Performance Liquid Chromatography; HRESIMS: High-resolution electrospray ionization mass spectrometry; HR-LCMS: High-resolution-liquid chromatography-mass spectrometry; IR: Infra-red; $L C_{50}$ : Concentration of test sample resulting in a $50 \%$ reduction of absorbance compared to untreated cells; LC-MS: Liquid chromatographymass spectrometry; MBC: Minimum bactericidal concentration; MDR: Multidrug-resistant; MHA: Mueller Hinton agar; MHB: Mueller Hinton broth; MIC: Minimum inhibitory concentration; MTT: 3-(4,5-dimethylthiazol-2-yl)-2,5-
}

diphenyltetrazolium bromide; NA: Nutrient agar; NMR: Nuclear Magnetic Resonance; PBS: Phosphate buffered saline; PDA: Potato dextrose agar; RPMI: Roswell Park Memorial Institute; Sl: Selectivity Index; TLC: Thin layer chromatography; UV: Ultra violet

\section{Acknowledgements}

JDT acknowledges funding from the Indian Ministry of Education and Research through their CV Raman fellowship grant. We also thank CAS (UGC) for providing partial contingency support at the Department of Biochemistry, University of Calcutta. This work was also supported by grants of the German Academic Exchange Service (DAAD), grant A/12/90548 to Jouda Jean-Bosco for his Ph.D. studies, DAAD initiative "Welcome to Africa" and the German Research Foundation (DFG) for funding a high-resolution mass spectrometer.

\section{Funding}

The study was funded by the Indian Ministry of Education and Research and the German Academic Exchange Service (DAAD).

\section{Availability of data and materials}

The datasets supporting the conclusions of this article are presented in this paper. Also, mass spectra for structure elucidation in this study are provided in the supporting information file.

\section{Authors' contributions}

$J B J, C D M$ and JDT carried out the study and wrote the manuscript; CDM, PS, PKB, and JW supervised the work. All authors read and approved the final manuscript.

\section{Competing interests}

The authors declare that they have no competing interests.

\section{Consent for publication}

No individual clinical data is presented in the article, the information is not relevant.

\section{Ethics approval and consent to participate}

Authorization for the collection of blood was obtained from the Medical and Ethical Committee (2013-10, in Kolkata, India). The written informed consent for participation in the study was obtained from a healthy parent.

\section{Author details}

'Department of Organic Chemistry, Faculty of Science, University of Yaoundé 1, P.O. Box 812, Yaoundé, Cameroon. ${ }^{2}$ Department of Biochemistry, Faculty of 
Science, Laboratory of Microbiology and Antimicrobial Substances, University of Dschang, P.O. Box 67, Dschang, Cameroon. ${ }^{3}$ Department of Biochemistry, University of Calcutta, 35 Ballygunge Circular Road, Kolkata 700 019, India. ${ }^{4} J u l i u s$ Kühn Institut, Federal Research Centre for Cultivated Plants, Institute for National and International Plant Health, Messeweg 11-12, D-38104 Braunschweig, Germany.

Received: 9 August 2015 Accepted: 31 October 2016

\section{Published online: 14 November 2016}

\section{References}

1. Petrini O. Ecological and physiological aspects of host-especificity in endophytic fungi. In: Redlin SC, Carris LM, editors. Endophytic fungi in grases and woody plants. Systematics, Ecology and Evolution. St. Pau: APS Press; 1996. p. 87-93.

2. Schulz B, Boyle C, Draeger S, Aust HJ, Römmert AK, Krohn K. Endophytic fungi: a source of novel biologically active secondary metabolites. Mycol Res. 2002;106:996-1004.

3. Schulz B, Boyle C. The endophytic continuum. Mycol Res. 2005;109:661-86.

4. Strobel G, Daisy B, Castillo U, Harper J. Natural products from endophytic microorganisms. J Nat Prod. 2004;67:257-68.

5. Scott PM, Harwig J, Chen Y-K, Kennedy BPC. Cytochalasins A and B from strains of Phoma exigua var. exigua and formation of cytochalasin B in potato gangrene. J Genet Microbiol. 1975;87:177-80.

6. Pribela A, Tomko J, Dolesjs L. Cytochalasin B from tomatoes contaminated by Hormiscium SD. Phytochemistry. 1975;14:285.

7. Aldridge DC, Armstrong JJ, Speake RN, Turner WB. Cytochalasins, a new class of biologically active mold metabolite. Chem Commun. 1967;1:26-7.

8. Patwardhan SA, Pandey RC, Dev S. Toxic cytochalasins of Phomopsis paspalli, a pathogen of Kodo millets. Phytochemistry. 1974;13:1985-8.

9. Wells JM, Cole RJ, Cutler HC, Spalding DH. Curualuria lunata, a new source of cytochalasin B. Appl Environ Microbiol. 1981;41:967-71.

10. Wells JM, Cole RJ, Cutler HC. Toxicity of plant growth regulators of cytochalasin H, isolated from Phomopsis sp. Phytopathol Can J Microbiol. 1976;22:1137-43.

11. Glinsukon T, Shank RC, Wogan GN, Newborne PM. Acute and subacute toxicity of cytochalasin E in the rat. Toxicol Appl Pharmacol. 1975;32:135-46.

12. Hayakawa TM, Matsushima T, Kimura T, Minato H, Katagiri K. Zygosporin A, a new antibiotic from Zygosporium masonii. J Antibiot. 1968:21:523-4.

13. Greenaway JC, Shepard TH, Kuc J. Comparison of cytochalasins (A, B, D, and E) in chick explants teratogenicity and tissue culture systems. Proc Soc Exp Biol Med. 1977;155:129-242.

14. Glinsukon T, Lekutai S. Comparative toxicity in the rat of cytochalasins B and E. Toxicon. 1980:17:137-44.

15. Shepard TH, Greenaway JC. Teratogenicity of cytochalasin D in the mouse. Teratology. 1977;16:131-6.

16. Fantel AG, Greenaway JC, Shepard TH, Juchau MR, Selleck SB. The teratogenicity of cytochalasin D and its inhibition by drug metabolism. Teratology. 1981;23:223-31.

17. Austin RB. Effective environment before harvesting on viability. In: Roberts EH, editor. Viability of seeds. London: Chapman and Hall Ltd; 1972. p. 114-49.

18. Wu SH, Chen YW, Shao SC, Wang LD, Li ZY, Yang LY, Li SL, Huang R. Ten-membered lactones from Phomopsis sp., an endophytic fungus of Azadirachta indica. J Nat Prod. 2008;71:731-4.

19. Ampofo AS, Waterman GP. Xanthones from three Garcinia species. Phytochemistry. 1986;25:2351-5.

20. Nilar Nguyen LHD, Venkatraman G, Sim KY, Harrison LJ. Xanthones and benzophenones from Garcinia griffithii and Garcinia mangostana. Phytochemistry. 2005;66:1718-23.

21. Iwu MM. Handbook of African Medicinal Plants. Boca Raton: CRC Press; 1993. p. 183-4.

22. Ofor MO, Nwufo MI, Ogoke IJ, Ngwuta AA, Ibeawuchi II, Duruigbo Cl. Postharvest storage characteristics of Bitter kola (Garcinia kola Heckel.) in imo state, Nigeria. N Y Sci J. 2010;3:6-9.

23. Austin WL, Wind M, Brown KS. Differences in the toxicity and teratogenicity and teratogenicity of cytochalasins $D$ and $E$ in various mouse strains. Teratology. 1982;25:11-8

24. Scherlach K, Hertweck C. Triggering cryptic natural product biosynthesis in microorganisms. Org Biomol Chem. 2009;7:1753-60.

25. Bag PK, Bhowmik P, Hajra TK, Ramamurthy T, Sarkar P, Majumder M Chowdhury G, Das SC. Putative virulence traits and pathogenicity of Vibrio cholerae Non-01, Non-0139 isolates from surface waters in Kolkata, India. Appl Environ Microbiol. 2008;74:5635-44.

26. NCCLS. Methods for dilution antimicrobial susceptibility tests for bacteria that grow aerobically, Approved Standards M7-A4. Wayne: National Committee for Clinical Laboratory Standards; 1997.

27. NCCLS. Methods for determining bactericidal activity of antimicrobial agents, Approved guideline, M26-A. Wayne: National Committee for Clinical Laboratory Standards; 1999.

28. Mosmann T. Rapid colorimetric assay for cellular growth and survival: application to proliferation and cytotoxicity assays. J Immunol Methods. 1983;65:55-63.

29. Situ H, Bobek LA. In vitro assessment of antifungal therapeutic potential of salivary histatin-5, two variants of histatin-5, and salivary mucin (MUC7) domain 1. Antimicrob Agents Chemother. 2000;44:1485-93.

30. Gao Y, Su YY, Sun W, Cai L. Diaporthe species occurring on Lithocarpus glabra in China, with descriptions of five new species. Fungal Biology. 2015; 119:295-309.

31. Udayanga D, Liu X, McKenzie EHC, Chukeatirote E, Bahkali AHA, Hyde KD. The genus Phomopsis: biology, applications, species concepts and names of common phytopathogens. Fungal Divers. 2011;50:189-225.

32. Shen L, Luo Q, Shen Z-P, Li L-Y, Zhang X-J, Wei Z-Q, Fu Y, Song Y-C, Tan R-X. A new cytochalasin from endophytic Phomopsis sp. IFB-E060. Chin J Nat Med. 2014;12:512-6.

33. Fu J, Zhou Y, Li H-F, Ye Y-H, Guo J-H. Antifungal metabolites from Phomopsis sp. by 254, an endophytic fungus in Gossypium hirsutum. Afr J Microbiol Res. 2011:5:1231-6.

34. Deshmukh PG, Kanitkar UK, Pendse GS. A new fungal isolated from Paspalum scrobiculatum, Linn. with new biologically active metabolites. Acta Microbiol Acad Sci Hung. 1975;22:253-62.

35. Bradburn N, Coker RD, Blunden G, Turner CH, Crabb TA. 5'-epialtenuene and neoaltenuene, dibenzo-a-pyrones from Alternaria alternata cultured on rice. Phytochemistry. 1994;35:665-9.

36. Tamokou JD, Mpetga Simo DJ, Lunga PK, Tene M, Tane P, Kuiate JR. Antioxidant and antimicrobial activities of ethyl acetate extract, fractions and compounds from the stem bark of Albizia adianthifolia (Mimosoideae). BMC Compl Altern Med. 2012;12:99

37. Betina V, Micekova D, Nemec P. Antimicrobial properties of cytochalasins and their alteration of fungal morphology. J Gen Microbiol. 1972;71:343-9.

38. Tanamatayarat $P$, Limtrakul $P$, Chunsakaow S, Duangrat C. Screening of some rubiaceous plants for cytotoxic activity against cervix carcinoma (KB-3-1) cell line. Thai J Pharm Sci. 2003;27:167-72.

39. Caamal-Fuentes E, Torres-Tapia LW, Simá-Polanco P, Peraza-Sánchez SR, Moo-Puc R. Screening of plants used in Mayan traditional medicine to treat cancer-like symptoms. J Ethnopharmacol. 2011;135:719-24.

40. Xu S, Ge HM, Song YC, Shen Y, Ding H, Tan RX. Cytotoxic cytochalasin metabolites of endophytic Endothia gyrosa. Chem Biodivers. 2009:6:739-45.

\section{Submit your next manuscript to BioMed Central and we will help you at every step:}

- We accept pre-submission inquiries

- Our selector tool helps you to find the most relevant journal

- We provide round the clock customer support

- Convenient online submission

- Thorough peer review

- Inclusion in PubMed and all major indexing services

- Maximum visibility for your research

Submit your manuscript at www.biomedcentral.com/submit
C) Biomed Central 